\title{
The Propensity for Mandatory Audit Rotation and its Impact on Earnings Management in Europe
}

\author{
R. REICHER ${ }^{1}$, T. N. BAO NGO² \\ 1Óbudai Egyetem, reicher.regina@kgk.uni-obuda.hu \\ ${ }^{2}$ VNUK Institute for Research and Executive Education, The University of Danang, tran.ngo@vnuk.edu.vn
}

\begin{abstract}
The doubt of investors for the accuracy of financial reporting statements and the credibility of external audit functions has becoming more and more severe in the recent years due to a variety of booming accounting scandals related to earnings management occurring around the world. To cope with these serious frauds in the world of financial market, many countries have adopted Mandatory Audit Rotation (MAR) rules. Although the MAR rule has been valid around European Union (EU) members since 2016, the effectiveness of this rule has not been examined in any academic papers yet. As a result, the aim of this study is to investigate the effectiveness and the necessity of the latest MAR rule in the EU by testing the influence of audit rotation activities and audit tenure on earnings management of companies in the STOXX Europe 600 Index. Practical implications of this study will not also prove whether companies in STOXX Europe 600 Index should be required to shorten their audit tenure by rotating their audit engagement more often in order to decline the degree of earnings management, but they will also help to strengthen support for the essentiality of MAR legislations in the EU if the result indicates that longer audit tenure actually leads to more earnings management of STOXX Europe 600 Index companies.
\end{abstract}

\section{Introduction}

The worldwide financial market since the beginning of the 21st century has experienced a large number of accounting scandals, most of which are associated with different levels of earnings management (e.g., Enron Corporation taking huge debts out of its balance sheet with the conviction of Big Five Arthur Andersen in 2001; WorldCom inflating eleven billion-dollar assets in 2002; Lehman Brothers Holdings hiding fifty billion-dollar loans with the suspicion of Big Four Ernst \& Young in 2008; Toshiba's admission of two billion- dollar earnings overstatement over seven years in 2015). To tackle with these shaming frauds in the financial market, many countries (e.g., the United States of America (U.S.) in 2002; the United Kingdom (UK) in 2012; the European Union (EU) in 2016) have enacted audit rotation rules in order to lower the degree of accounting frauds and to strengthen audit quality. The effectiveness of audit rotation in preventing earnings management and the essentiality of MAR enactment have received a lot of concern from academic researchers; however, there have still been controversies in academic world around this issue.

In the EU, companies in EU country members have been required to tender their audit engagement every ten years since June $17^{\text {th }}$, 2016. In terms of the impact of audit rotation on earnings management, there were several researchers investigating this issue; however, there has been little empirical study about its actual impact after the introduction of the new audit rotation rule in the EU in 2016. Thus, the 
need to explore the capability and the essentiality of this new rule in addressing earnings management issues in the EU is still a gap in academic world. Additonally, the audit rotation research theme has focused mostly on the impact of audit tenure rather than the number of times that a firm has changed its auditor over a period of time. These huge gaps in academic literature actually pave the way for this research to be undertaken to test the role of audit rotation activities, represented by the numbers of auditors employed in ten years, and audit tenure on lowering the degree of earnings management in EU stock market.

This research intends to use the sample of companies listed in the STOXX Europe 600 Index to test the research' s hypotheses, as the STOXX Europe 600 Index comprised 600 small, medium and large companies in the EU financial market. The investigated period of time is a ten-year period between 2006 and 2015. The financial data of STOXX Europe 600 Index from 2006 and 2015 used in this study are expected to acquire from the Datastream database. This study will use discretionary accruals as a proxy to estimate the degree of earnings management basing on research of Matsumoto (2002); Myers et al. (2003); Davis et al., (2009). Discretionary accruals were calculated through the modified Jones Model suggested by Dechow et al. (1995), since this model was proved to be the most accurate method to test earnings management in Dechow et al. (1995)'s research.

This research should make a great contribution to the growing body of audit rotation in two ways. Firstly, there are new proxies for this academic field proposed in this study. In particular, the use of the number of auditors as a main proxy for audit rotation activities may have not appeared in previously related academic research. Additionally, this research also adds the new dummy variable Big4 to control the influence of the audit rotation occurring within or outside Big Four audit companies. Secondly, as the considered period of time in this research includes years before and after the enactment of the new audit rule in the EU, the research can draw a latest and comprehensive picture about the impact of audit rotation on earnings management strategies of STOXX Europe 600 Index companies.

However, due to some difficulties to access to Datastream Database in Hungary, the research cannot collect enough data to run the regression models. In spite of that, the expected results are believed suggest two main points. The first supposed result will be consistent with the results from prior research of Davis et al. (2009), Lennox et al. (2014) and Bell et al. (2015) when showing that the larger number of auditors empolyed by each firm in ten years, the lower degree of earnings management. If that, this result will be the confirmation for the effectiveness of MAR on decreasing earnings management in the EU. Besides, the second is believed to prove that longer tenure can result in more earnings management strategies, which will then affirm the fundamental need of MAR enactment in the EU.

In the following part, the research demonstrates theoretical information about earnings management, the general background information about MAR and presents the review of prior related research, which then paves the way for the development of two hypotheses on the effect of audit rotation activities and audit tenure on earnings management. The following part illustrates the research method and the formation of two regression models. Finally, the research draws conclusions, points out any limitations and makes several suggestions for future research.

\section{Literature Review}




\subsection{Mandatory Audit Rotation Rules}

In order to confront with the widespread of accounting frauds, many countries around the world have enacted the Mandatory Audit Rotation rule with the hope to lower the degree of financial report misleading and enhance the audit quality. In one article pulished in 2015, the Ernst \& Young Global Limited (EY) summarised the MAR rule in some countries around the world as followed:

\begin{tabular}{|c|c|c|c|}
\hline Country & $\begin{array}{l}\text { Partner } \\
\text { rotation }\end{array}$ & Audit firm rotation & Source \\
\hline Australia & 5 years & No & http://www.cpaaustralia.com.au \\
\hline Austria & 5 years & $\begin{array}{l}5 \text { years for governmental owned } \\
\text { companies }\end{array}$ & $\begin{array}{l}\text { EY Transparency Report } 2014 \text { and https://www. } \\
\text { crowehorwath.net }\end{array}$ \\
\hline Belgium & 6 years & $\begin{array}{l}\text { No (reappointment every } 3 \text { years with } \\
\text { no limits) }\end{array}$ & Ewelt-Knauer et al. (2012) \\
\hline Brazil & No & 5 years & Harris and Whisenant (2012) \\
\hline Bulgaria & 5 years & No & http://www.crowehorwath.net \\
\hline Canada & 7 years & No & http://www.cga-canada.org \\
\hline China & 5 years & $\begin{array}{l}5 \text { years for financial institutions and } \\
\text { state-owned enterprises (there must be } \\
\text { a tender process every } 3 \text { years) }\end{array}$ & Lennox et al. (2014) and http://economia.icaew.com \\
\hline Croatia & 7 years & $\begin{array}{l}7 \text { years for banks and } 4 \text { years for insurance } \\
\text { and leasing companies }\end{array}$ & http://anale.feaa.uaic.ro/ and Ewelt-Knauer et al. (2012) \\
\hline Cyprus & 7 years & No & EY Transparency Report 2013 \\
\hline $\begin{array}{l}\text { Czech } \\
\text { Republic }\end{array}$ & 7 years & No & Ewelt-Knauer et al. (2012) \\
\hline Denmark & 7 years & No & EY Transparency Report 2014 \\
\hline Estonia & & & 7 years \\
\hline Finland & 7 years & No & Ewelt-Knauer et al. (2012) \\
\hline France & 6 years & $\begin{array}{l}\text { No ( } 6 \text { years with joint audit but may } \\
\text { be renewed) }\end{array}$ & André et al. (2015) and Francis et al. (2009) \\
\hline Germany & 7 years & No & Ewelt-Knauer et al. (2012) \\
\hline Greece & 7 years & No & EY Transparency Report 2013 \\
\hline Hungary & 7 years & No & Information retrieved directly via the EY network \\
\hline Ireland & 5 years & No & http://www.cpaireland.ie \\
\hline
\end{tabular}




\begin{tabular}{|c|c|c|c|}
\hline Country & Partner rotation & Audit firm rotation & Source \\
\hline Italy & 7 years & 9 years & Cameran et al. (2015a) \\
\hline Latvia & 7 years & No & EY Transparency Report 2014 \\
\hline Lithuania & $\begin{array}{l}5 \text { years for PIEs; } 7 \text { years } \\
\text { for some other legal } \\
\text { entities }\end{array}$ & No & http://www3.Irs.It/ \\
\hline Luxembourg & 7 years & No & Ewelt-Knauer et al. (2012) \\
\hline Malta & 7 years & No & EY Transparency Report 2013 \\
\hline Poland & 5 years & No & Information retrieved directly via the EY network \\
\hline Portugal & 7 years & $\begin{array}{l}\text { No ( } 8-9 \text { years for listed companies } \\
\text { on a "comply or explain" rule) }\end{array}$ & Ewelt-Knauer et al. (2012) \\
\hline Romania & 7 years & No & http://www.crowehorwath.net \\
\hline Singapore & $\begin{array}{l}5 \text { years for listed } \\
\text { companies: } \\
7 \text { years for other PIEs }\end{array}$ & No & Information retrieved directly via the EY network \\
\hline Slovakia & 5 years & 5 years & http://www.crowehorwath.net \\
\hline Slovenia & 7 years & $\begin{array}{l}5 \text { years for the banking and } \\
\text { insurance industry, only }\end{array}$ & Ewelt-Knauer et al. (2012) \\
\hline South Korea & No & No & Kwon et al. (2014) \\
\hline Spain & 7 years & No & Ruiz-Barbadillo et al. (2009) \\
\hline Sweden & 7 years & No & http://lup.lub.lu.se/search/ \\
\hline $\begin{array}{l}\text { The } \\
\text { Netherlands }\end{array}$ & 7 years & No & http://ey.com/Publications \\
\hline Turkey & 5 years & 7 years & Information retrieved directly via the EY network \\
\hline U.K. & 5 years & 10 years starting 1 January 2015 & https://www.gov.uk/ \\
\hline U.S. & 5 years & No & See below \\
\hline
\end{tabular}

Source: EY Global Financial Services Institute. (2015)

Figure 1.1 below draws an illustrative picture of important events related to MAR rule in the EU.

The European Commission (E.C.) issued E.C. Directive 2006/43/EC:

- Key audit partner rotation is mandated after seven years in public interest entities (PIEs)

- The key audit partner shall not be able to participate in the audit of the same entity for at least two years Member States were given two years to implement the directive (until Mid-2008)
The European Parliament proposed audit firm rotation as mandatory at 25 years.

However, after Germany and Austria voted strongly against such a long tenure, it was to be reduced to 21 years

To strengthen audit reports quality, a new statutory audit framework was introduced through Directive 2014/56/EU and Regulation 537/2014:

- The audit firm tenure for PIEs will be limited to 10 years. The same audit firm can be reappointed for another 14 years in case of joint audits or for another 10 years in the case of a public tender.

- The partner rotation remains mandatory after seventh engagementyear

Figure 1.1. Auditing events in the EU Source: EY Global Financial Services Institute (2015)
The European Commission (E.C.) issued E.C. Directive 2006/43/EC:

- Key audit partner rotation is mandated after seven years in public interest entities (PIEs)

- The key audit partner shall not be able to participate in the audit of the same entity for at least two years Member States were given two years to implement the directive (until Mid-2008) 


\subsection{Earnings Management}

Earning management is the case that organization managers manipulate financial reports legally or illegally to demonstrate an untrue picture of the firm's financial conditions.

'Earnings management occurs when managers apply their judgment to financial reporting, and/or construction of transactions in order to change financial reports and mislead stakeholders on issues concerning the operational performance of companies or they may alter the contractual results based on accounting numbers'

Chen and Tsai, 2010, p.955

As investors normally have a tendency to assess good earnings as a positive sign for a firm's financial health, many managers try to manage their earnings in order to meet the investors' expectation. In a research of Bailey, Karolyi and Salva (2006); Bae, Cheon and Kang (2008), investors and bondholders are proved to perform strong reaction to firms' earnings announcements. It is the influence of earnings reports on investor behaviour that incentivize managers to choose their earnings-optimizing financial reporting strategies (Abarbanell and Lehavy, 2003; Goel and Thakor, 2003). Then, earnings management is an effective tool for managers to increase earnings with the intention of confronting future earnings disappointments (Burgstahler and Dichev, 1997a; Matsumoto, 2002; Burgstahler and Eames, 2006).

However, the benefits gained from earnings management appear to be only for the short term. According to Brooks (2010), shareholders may gradually find it more difficult to predict correct risk or return evaluation, sooner or later the lenders would discover that they have been misled. Losing trust and confidence from the investors and creditors in this course of action is the biggest managerial mistake that can defeat even the strongest organizations, as long-term business does not stand a chance without the support of its stakeholders. Thus, the negative consequences suffered from earnings manipulation would far outweigh the benefits acquired.

\subsection{Mandatory audit rotation activities}

As regards reasons given to approve of the MAR enactment, as emphasized by The Conference Board (2003), audit rotation could bring 'a fresh look' (The Conference Board, 2003, p.39) to corporate's finance, and the work of an auditor could improve due to the peer pressure from his or her successor auditors. According to Lennox et al. (2014), the peer review between predecessor and successor auditors paves the way for the higher detection of financial reporting frauds, which can result in the significant audit adjustment in last years of an audit term. Using data from non-financial companies on the Milan Stock Exchange between 1985 and 2004 and applying an accruals-based measure, Cameran, Prencipeand, Trombetta (2016)'s research result also supports what is indicated in Lennox et al. (2014)'s research. These researchers point out that higher audit quality in the last years will occur as auditors become more conservative towards the conclusion of the auditing term. If a company does not have to change their external auditors after a number of years, it cannot witness the higher audit quality in the first and last years of an auditing term. 
However, many people neither support for nor believe in the capability of MAR. As noticed in the study conducted by the U.S. General Accounting Office (GAO) in 2003, the drawbacks of MAR are suggested to be the lack of specific knowledge about a firm of a new auditor. Researches conducted by Davis, Soo and Trompeter, 2009; Daugherty et al., 2012; Litt et al., 2014; Bell, Causholli and Knechel, 2015 also demonstrate that the unfamiliarity of new auditors with their clients lead to low audit quality in the first several years of an auditing term. Besides, the research of Carcello and Nagy (2004) shows that: '... companies that change auditors are more likely to have financial reporting problems, rather than reflecting any problems with the audit process itself during the early years of the auditor-client relationship' (Carcello and Nagy, 2004, p.67).

Overall, the potentiality of MAR has received widespread concern from legislators, regulators and academic researchers as well as all economic entities. Although the effectiveness of MAR has been examined many times, the results collected remain conflicting and have not yet led to final agreements. Based on the belief of MAR legislators and supporters, the first hypothesis is built as the following:

\section{Hypothesis 1: More audit rotation activities have a statistically positive effect on lessening the degree of earnings management.}

\subsection{Audit tenure}

Besides the concern about the validation of MAR, researchers also raise a question about the relationship between the length of an auditing term and financial reporting quality. Similar to studies regarding MAR, the results from audit tenure researches are also mixed, leading to the current global debate about audit tenure.

As stated before, one of the fundamental targets of MAR is to shorten the long audit tenure of most companies, which is considered as the root of weak auditor independence. In academic research, Lennox et al. (2014) strengthen the approving opinion on MAR enactments by indicating that a strong mutual bond between auditors and firms in a long auditor-client relationship, which leads to poor audit quality and low independence, could be hampered thanks to MAR. Bell et al. (2015) and Davis et al. (2009) similarly discovered that the longer the audit tenure, the higher the discretionary accruals, which are currently proxies for earnings management evaluation. In addition, according to Davis et al. (2009), Harris and Whisenant (2012) and Bell et al. (2015), although the audit quality of first-year auditors is not assessed to be high, the audit quality will gradually experience a significant improvement in the following years. However, after several-years of improvement, the longer the audit tenure, the weaker the reliability of the financial reporting statements. Thus, what can be learned from research of Davis et al. (2009), Harris and Whisenant (2012) and Bell et al. (2015) is that long audit tenure should be avoided as it results in poor audit quality. Hence, the elimination of auditor independence and accounting frauds due to long auditor-client relationship may be considered as the most principal intention of MAR enactments.

On the other hand,, Bell et al. (2015)'s research mention the accumulated client-specific knowledge of long-term auditors, which could contributes to higher audit quality. However, several researchers suggest that there is no relation between audit tenure and financial reporting quality; therefore, it should be unnecessary to apply MAR to reduce the weakening of auditor independence. The finding 
about the non-correlated relationship between long audit-firm tenure (over nine years) and financial reporting quality is stated by the research conducted by Johnson et al. (2002), who use the data of Big Six clients in US between 1986 and 1995 and two proxies for financial reporting quality evaluation (unexpected accruals and future income), and Knechel and Vanstraelen (2007), who review data of 618 private Belgian companies.

Hence, the relationship between audit tenure and earnings management detection is still the contentious topic among academic researchers, and it needs to be determined in further research. Consistent with the reason for MAR enactment, the second hypothesis of this research is given as follows:

Hypothesis 2: Longer audit tenure has a statistically positive influence on the increase in the degree of earnings management.

\section{Methodology}

\subsection{Data}

The sample firms used to answer the two research questions are all firms listed in STOXX EUROPE 600 INDEX The STOXX EUROPE 600 INDEX companies are selected because the STOXX EUROPE 600 INDEX consists of 600 small, medium and large companies listed in the STOXX EUROPE 600 INDEX instead. All the data used in this research will be secondary data extracted from Datastream database.

Yearly historical financial data of STOXX EUROPE 600 INDEX companies are scrutinized for the period between 2009 and 2018, because this period experienced a variety of significant occurrences in the worldwide financial market. the ten-year audit tendering rule for STOXX EUROPE 600 INDEX companies in 2016 .

\subsection{Multivariate regression models}

The modified cross-sectional model of discretionary accruals, which was developed by Dechow et al. (1995) from the Jones Model, is used to get discretionary accruals. According to Dechow et al. (1995)'s research, the modified version of the Jones Model is the most effective method to test earning managements behaviour for an event-years sample, because this model controls the change in firms' receivables and contains less bias in earnings managements measurement. This study uses Eviews for the statistical and econometrics analysis. Regression models adopted in this research are semilogarithmic models (log-lin models). The method adopted to estimate two regression models mentioned above will be Ordinary Least Square (OLS) method.

The first target of this study is to examine the effectiveness of MAR rule in the UK by exploring whether the audit rotation activities can make a contribution to preventing earnings management strategies. Therefore, the hypothesis is given below:

Hypothesis 1: More audit rotation activities have a statistically positive effect on lessening the degree of earnings management. 
The first multivariate regression model to test Hypothesis 1 is estimated as the following:

$$
\begin{aligned}
& L D A_{i, t}=\beta_{0}+\beta_{1} N U M B E R \_O F_{-} A U D I T O R S+\beta_{2} C H A N G E_{-} O N C E \\
& +\beta_{3} \text { CHANGE_MORE_THAN_ONCE }+\beta_{4} \text { BIG4 }+\beta_{5} S I Z E_{(\text {CONTROL })}
\end{aligned}
$$

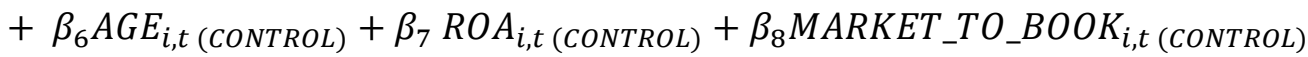

$$
\begin{aligned}
& +\beta_{9} \text { LEVERAGE }_{i, t(\text { CONTROL })}+\beta_{10} \text { CASHFLOW }_{i, t(\text { CONTROL })}+\varepsilon_{i, t}
\end{aligned}
$$

On the other hand, the second goal of this study is to test the necessity of MAR enactment. As mentioned in the Literature Review chapter, accounting frauds are thought to have their roots from long audit tenure MAR legislators and supporters; thus, it is necessary to enact MAR rules. Therefore, the essentiality of MAR enactment in the UK will be reaffirmed if longer audit tenure is proved to result in more earnings management if STOXX EUROPE 600 INDEX companies. Based on this belief, the second hypothesis of this study is given below:

\section{Hypothesis 2: Longer audit tenure has a statistically positive influence on the increase in the degree of earnings management.}

In order to test Hypothesis 2, the multivariate regression model is built as the following:

$$
\begin{aligned}
& L D A_{i, t}=\beta_{0}+\beta_{1} \text { TENURE }+\beta_{2} S H O R T+\beta_{3} L O N G+\beta_{4} B I G 4+\beta_{5} S I Z E_{(\text {CONTROL })}+ \\
& \beta_{6} A G E_{i, t(\text { CONTROL })}+\beta_{7} \text { ROA }_{i, t(\text { CONTROL })}+\beta_{8} \text { MARKET_TO_BOOK } \text { i,t }(\text { CONTROL })+ \\
& \beta_{9} L_{E V E R A G E} i_{i, t(\text { CONTROL })}+\beta_{10} \text { CASHFLOW }_{i, t(\text { CONTROL })}+\varepsilon_{i, t}
\end{aligned}
$$

where:

LDAi,t

$=\log$ of discretionary accruals of firm i in year $\mathrm{t}$, a proxy for the degree of earnings management.

NUMBER OF AUDITORS = number of auditors employed by each firm from 2000 to 2015 .

CHANGE_ONCE = the situation when a firm changes its auditor once in ten years, dummy variable equalling to 1 for this situation; 0 otherwise.

CHANGE_MORE_THAN_ONCE $=$ the situation when a firm changes its auditor more than once in ten years, dummy variable equalling to 0 for this situation; 0 otherwise.

BIG4 $=$ auditor switch within Big Four or keeping one Big Four auditor in ten years dummy variable equalling to 1 if a firm change its auditor from one Big Four to another; 0 otherwise.

TENURE $=$ the number of years of a continuous auditor-client engagement.

SHORT = short audit tenure, dummy variable equalling 1 for 3 years and less of auditor-client relationship; 0 otherwise.

LONG $=$ long audit tenure, dummy variable equalling 1 for ten years and more of auditor-client relationship; 0 otherwise. 
AGE

ROA i,t

MARKET TO BOOK i,t

LEVERAGEi,t

CASHFLOWi,t
= firm age of firm i in year 2015, defined as number of years the firm listed in the Index.

= return on assets listed in the Index, defined as the ratio of net income to total assets.

$=$ market to book value of firm $\mathrm{i}$ in year $\mathrm{t}$, defined as the ratio of market capitalization to book value of equity.

$=$ leverage ratio of firm $\mathrm{i}$ in year $\mathrm{t}$, defined as the ratio of total debt to total assets.

= firms' cash flow of firm i in year $t$, defined as the ratio of operating cash flow to total assets.

\section{Conclusion}

In these recent years, the mushrooming increase in the number of accounting scandals, which are mostly related to earnings management, and the worrisome drop in audit quality have gradually eroded investors' confidence in financial reporting statements and have posed a question about external auditor credibility. In order to address this emerging issue in financial reporting, audit rotation requirement rules have been enacted in many countries. This study is designed in the context of over three years after the MAR enacted in the EU, so that it can help to satisfy the urgent need for research about the efficiency of this MAR rule in lowering the degree of earnings management and enhancing the audit quality. The first question aims to test the capability of MAR in the EU by examining whether more audit rotation activities, which are presented by the number of auditors employed by STOXX EUROPE 600 INDEX companies from 2009 to 2018, can contribute to lowering the degree of earnings management. The second one tries to confirm the necessity of MAR enactment by scrutinizing whether longer audit tenure actually results in the rising level of earnings management.

Although the findings have not reached yet because of the lack of database, this research is believed to bring new perspectives and evidence to the growing body of literature about the relationship between audit rotation and earnings management in the future. It will be needed for both rule legislators to test the right of their rule enactment decision, investors, auditors and all stock market entities.

Further research can be conducted with the purpose of recommending either the number of times that each company should switch its auditor within a specific period of time, or the best appropriate audit tenure of each auditor-client relationship to achieve the ultimate objectives of MAR in weakening the level of earnings management. Furthermore, investigating how auditor switches occurring within or outside Big Four affects the capability of MAR will be another helpful addition to this research area. The relationship between the competition in audit industry and MAR is well worth considering in future audit rotation research. Finally, further research on UK financial market is suggested to be undertaken with longer investigated of time to provide more clear evidence for the effectiveness of MAR. The 
observation of STOXX EUROPE 600 INDEX companies in the recommended time frame could draw a clearer picture about the effect of audit rotation on earnings management in the EU.

\section{References}

[1] Abarbanell, J. and Lehavy, R. (2003) 'Can Stock Recommendations Predict Earnings Management and Analysts' Earnings Forecast Errors?', Journal of Accounting Research, 41(1), pp.1-31.

[2] Bae, G.S., Cheon, Y.S. and Kang, J. (2008) 'Intragroup Propping: Evidence from the Stock-Price Effects of Earnings Announcement by Korean Business Groups', The Review of Financial Studies, 21(5), pp.2015-2060.

[3] Bailey, W., Karolyi, G.A. and Salva, C. (2006) 'The economic consequences of increased disclosure: Evidence from international cross-listings', Journal of Financial Economics, 81(1), pp.175-213.

[4] Bedard, J.C. and Johnstone, K.M. (2010) 'Audit Partner Tenure and Audit Planning and Pricing', Auditing: A Journal of Practice \& Theory, 29(2), pp.45-70.

[5] Bell, T.B., Causholli, M. and Knechel, W.R. (2015) 'Audit Firm Tenure, Non-Audit Services, and Internal Assessments of Audit Quality', Journal of Accounting Research, 53(3), pp.461-509.

[6] Brooks JR, L. (2010) 'Earnings Management', in Kolb, R. (ed.) Robert W. Kolb Series: Finance Ethics: Critical Issues in Theory and Practice (1). New Jersey: John Wiley \& Sons, Inc., pp.457473.

[7] Burgstahler, D. and Dichev, I. (1997a) 'Earnings management to avoid earnings decreases and losses', Journal of Accounting and Economics, 24(1), pp.99-126.

[8] Burgstahler, D. and Eames, M. (2006) 'Management of Earnings and Analysts' Forecasts to Achieve Zero and Small Positive Earnings Surprises', Journal of Business Finance and Accounting, 33(5-6), pp.633-652.

[9] Cameran, M., Prencipe, A. and Trombetta, M. (2016) 'Mandatory Audit Firm Rotation and Audit Quality', European Accounting Review, 25(1), p.35-58.

[10] Carcello, J.V. and Nagy, A.L. (2004) 'Auditing Firm Tenure and Fraudulent Financial Reporting', Auditing: A Journal of Practice \& Theory, 23(2), pp.55-69.

[11] Chen, M.C. and Tsai, Y.C. (2010) 'Earnings Management types and motivation', Social Behaviour and Personality, 38(7), pp.955-962.

[12] Daugherty, B.E., Dickins, D., Hatfield, R.C. and Higgs, J.L. (2012) 'An Examination of Partner Perceptions of Partner Rotation: Direct and Indirect Consequences to Audit Quality', Auditing: A Journal of Practice \& Theory, 31(1), pp.97-114.

[13] Davis, L.R., Soo, B.S. and Trompeter, G.M. (2009) 'Auditor Tenure and the Ability to Meet or Beat Earnings Forecasts', Contemporary Accounting Research, 26(2), pp.517-548. 
[14] Dechow, P.M. (1994) 'Accounting earnings and cash flows as measures of firm performance. The role of accounting accruals', Journal of Accounting and Economics, 18(1), pp.3-42.

[15] Dechow, P.M., Sloan, R.G. and Sweeney, A.P. (1995) 'Detecting Earnings Management', The Accounting Review, 70(2), pp.193-225.

[16] EY Global Financial Services Institute. (2015) . Article: The audit mandatory rotation rule: the state of the art. The Journal of Financial Perspectives. Volume 3 - Issue 2

[17] Goel, A.M. and Thakor, A.V. (2003) 'Why do firms smooth earnings?', Journal of Business, 76(1), pp.151-192.

[18] Harris, K. and Whisenant, S. (2012) 'Mandatory audit rotation: An international investigation', Working paper, The University of Houston.

[19] Johnson, V.E., Khurana, I.K. and Reynolds, J.K. (2002) 'Audit-Firm Tenure and the Quality of Financial Reports', Contemporary Accounting Research, 19(4), pp.637-660.

[20] Jones, J.J. (1991) 'Earnings Management During Import Relief Investigations', Journal of Accounting Research', 29(2), pp.193-228.

[21] Knechel, W.R. and Vanstraelen, A. (2007) 'The Relationship between Auditor Tenure and Audit Quality Implied by Going Concern Opinions', Auditing: A Journal of Practice \& Theory, 26(1), pp.113-131.

[22] Lennox, C. (2014) 'Auditor tenure and rotation', in Hay, D., Knechel, W.R. and Willekens, M. (ed.) The Routledge Companion to Auditing. London: Taylor \& Francis Ltd, pp.89-106.

[23] Lennox, C.S., Wu, X. and Zhang, T. (2014) 'Does Mandatory Rotation of Audit Partners Improve Audit Quality?', The Accounting Review, 89(5), pp.1775-1803.

[24] Litt, B., Sharma, D.S., Simpson, T. and Tanyi, P.N. (2014) 'Audit Partner Rotation and Financial Reporting Quality', Auditing: A Journal of Practice \& Theory, 33(3), pp.59-86.

[25] Lu, T. and Sivaramakrishnan, K. (2009) 'Mandatory audit firm rotation: Fresh look versus poor knowledge', Journal of Accounting and Public Policy, 28(2), pp.71-91.

[26] Matsumoto, D.A. (2002) 'Management's Incentives to Avoid Negative Earnings Surprises', The Accounting Review, 77(3), pp.483-514.

[27] Myers, J.N., Myers, L.A. and Omer, T.C. (2003) 'Exploring the Term of the Auditor-Client Relationship and the Quality of Earnings: A Case for Mandatory Auditor Rotation?', The Accounting Review, 78(3), pp.779-799.

[28] Nagy, A.L. (2005) 'Mandatory Audit Firm Turnover, Financial Reporting Quality, and Client Bargaining Power: The Case of Arthur Andersen', Accounting Horizons, 19(2), pp.51-68.

[29] Public Company Accounting Oversight Board (PCAOB) (2011) Concept release on auditor independence and audit firm rotation. Washington D.C.: The Office of the Secretary, PCAOB.

[30] The U.S. Government Accountability Office (GAO) (2003) PUBLIC ACCOUTING FIRMS: Required Study on the Potential Effects of Mandatory Audit Firm Rotation. Available at: 
http://www.gao.gov/new.items/d04216.pdf (Accessed: 07 May 2016)

[31] The Conference Board (2003) Commission on Public Trust and Private Enterprise. New York: The Conference Board, Inc.

[32] The Public Company Accounting Oversight Board (PCAOB) (2011) CONCEPT RELEASE ON AUDITOR INDEPENDENCE AND AUDIT FIRM ROTATION; NOTICE OF ROUNDTABLE. Washington, D.C.: The Public Company Accounting Oversight Board. 